8 M.N. Galbraith, D.H.S. Horn, E.J. Middleton and R.J. Hackney, Chem. Commun. 2, 83 (1968).

9 M. Locke, Tissue Cell 1, 103 (1969).

10 S. Bonner-Weir, Nature, Lond. 228, 580 (1970).

11 H. Moriyama, K. Nakanishi, D.S. King, T. Okauchi, J.B. Siddall and W. Hafferl, Gen. comp. Endocr. 15, 80 (1970).

12 F. Romer, Naturwissenschaften 58, 324 (1971).

13 V.B. Wigglesworth, in: The control of growth and form: a study of the epidermal cell in an insect, p. 140. Cornell Univ. Press, 1959.
14 P. Karlson and C.E. Sekeris, Nature, Lond. 195, 183 (1962a).

15 P. Karlson and C.E. Sekeris, Recent Prog. Horm. Res. 22, 473 (1966).

16 A.C.S. Crossley, J. exp. Zool. 157, 375 (1964).

17 C.E. Sekeris and P. Karlson, Archs Biochem. Biophys. 105, 483 (1964).

18 G. Fraenkel and C. Hsiao, J. Insect Physiol. 13, 1387 (1967).

19 D.L. Whitehead, FEBS Letters 7, 263 (1970).

20 R.P. Bodnaryk, Gen. comp. Endocr. 16, 363 (1971a).

\title{
Correlation of song frequency and body weight in passerine birds
}

\section{Wallschläger}

Sektion Biologie der Humboldt-Universität, Invalidenstr. 43, DDR-104 Berlin (German Democratic Republic), 5 June 1979

Summary. Frequency analysis of the songs of 90 European passerine species shown a correlation with body weight. In a number of species a dependence on habitat was found.

Various physiological parameters of homeothermic vertebrates such as heart beat, respiratory and metabolic rates exhibit a strong dependence on body weight ${ }^{l}$. A similar relation was suggested for the vocalization of birds by Schwartzkopf $f^{2}$. This problem area was examined in a comprehensive study of the song frequencies of European passerine birds.

Material and methods. The songs of 90 passerine species recorded in the open field on UHER and NAGRA tape recorders were analyzed using a 1/3-octave filter (TOA 111) thus yielding species-specific vocalization spectra. At least 3 song sequences of each individual and of 3 individuals of each species were analyzed. Species-specific centre frequencies were found by calculating the geometric mean of each spectrum. These frequencies were compared with the body weights of the species. Mean body weights were taken from larger samples in the literature ${ }^{3}$.

Results. The figure 1 illustrates the relation found between song centre frequency and average body weight of the species studied. Frequencies range from $1.25 \mathrm{kHz}$ (Corvus

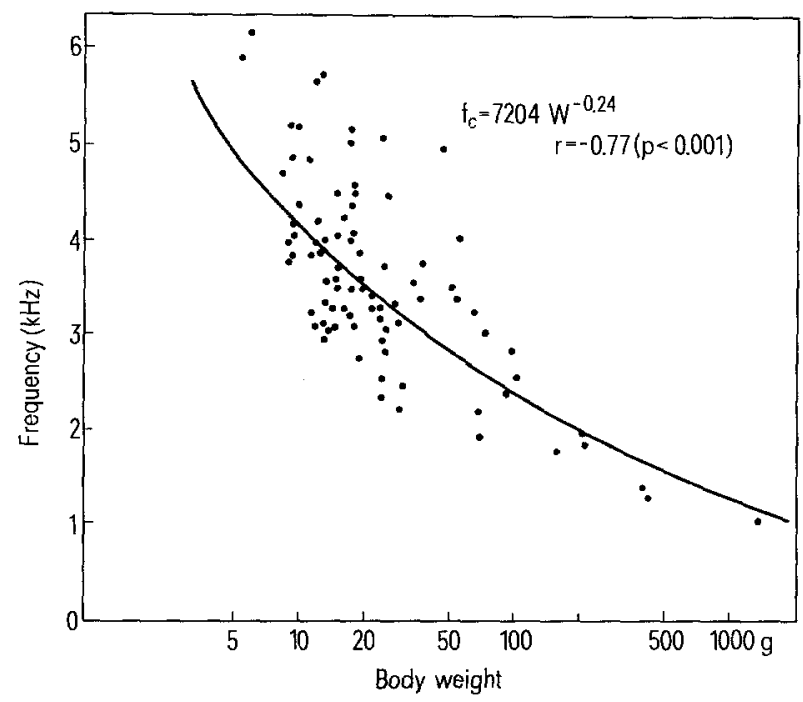

Relation between song centre frequency and average body weight of 90 European passerine species: The relation may be expressed by a regression function with high significantly correlation. corax) to $6.13 \mathrm{kHz}$ ( $R$. regulus), b.wt from $5.3 \mathrm{~g}$ (Regulus ignicapillus) to $1400 \mathrm{~g}$ (Corvus corax). The relation between centre frequency and body weight may be expressed by the regression function $\mathrm{f}_{c}=7.204 \mathrm{~W}^{-0.24}$ ( $\mathrm{f}_{c}$ in $\mathrm{kHz}$ and $\mathrm{W}$ in $\mathrm{g}$ ). The correlation coefficient $r$ has the value 0.77 . This value is significant with $\mathrm{p}<0.001$.

A closer analysis shows certain marked disparities for which ecological factors appear to be responsible. Thus species living in open habitats (field and meadow) exhibit higher frequencies than expected whereas the converse true for species occupying homogeneous habitats (rush) ${ }^{4}$.

Discussion. The relation found between mean song frequency and body weight shows that bird vocalization is highly dependent on constitution. As vocalization depends to a high degree on anatomical factors (length of trachea, resonance capacity etc.) as well as physiological factors (respiratory ratel) such a correlation is to be expected. It is interesting to note in this context that the value found for the exponent of the regression function $(-0.24)$ corresponds closely to values for the regression functions for heart beat rate $\left(-0.21\right.$ to $\left.-0.25^{1,5,6}\right)$ and respiratory rate $\left(-0.26^{l}\right)$ over body weight in homeothermic animals; it would appear that a general relation exists.

Birds also have the capacity to adapt their vocalization to ecological factors. Studies reported previously, however, express one-sided points of view: body weight is either totally ${ }^{7}$ or partly ${ }^{8}$ ignored thus giving ecological factors priority in the selection process, or as in the case of other authors ${ }^{9}$ it is assumed that only body weight influences vocalization. Ultimately a synthesis of both points of view must emerge.

1 K. Schmidt-Nielsen, in: Scale Effects in Animal Locomotion, p. 1. Ed. T. J. Pedley, Academic Press, New York 1977.

2 J. Schwartzkopff, Acta XI. Congr. Int. Orn. 1954, 189 (1955).

3 N.V. Vinogradova, V.R. Dolnik, V.D. Jefremov and V.A. Pajevski, Determining sex and age in passerine birds of the U.S.S.R., Nauka, Moscow 1976.

4 D. Wallschläger, in preparation.

5 M. Berger, J.S. Hart and O.Z. Roy, Z. vergl. Physiol. 66, 201 (1970).

6 S. Daan and S. Slopsema, J. comp. Physiol. 127 A, 215 (1978).

7 E. S. Morton, Am. Nat. 109, 17 (1975).

8 C. Chappuis, terre vie 2, 183 (1971).

9 H.-H. Bergmann, Z. Tierpsychol. 42, 315 (1976). 